Nelson Nefussi, engenheiro químico e sanitarista; mestre em ciência em higiene e poluição do ar (Universidade de Pittsburgh), exdiretor da Cetesb. Atualmente é consultor da

OPS/OMS, consultor da FIESP/CIESP, membro da União dos Defensores da Terra OIKOS e diretor da Nefussi e Consultores de Meio Ambiente S/C Ltda.

\title{
Poluição do ar nas áreas metropolitanas de São Paulo - situação até março de 1983
}

\section{Introdução}

Nas áreas metropolitanas, tendo em vista, principalmente, o rápido crescimento urbano e industrial, freqüentemente, de uma forma espacial desordenada, com conseqüente apresentação de altas densidades populacionais e de atividades econômicas, são gerados problemas de ordem social, especialmente sanitários, cujo equacionamento e solução são extremamente complexos, representando verdadeiros desafios à administração pública. Dependendo da característica de cada país, esta citada complexidade pode ser agravada por diversos fatores, entre os quais, por serem importantes no Brasil, em especial no Estado de São Paulo, cumpre destacar:

- fator econômico financeiro: falta de recursos (receitas públicas) suficientes para atender a solução dos problemas (despesas públicas) existentes. Cabe neste caso uma crítica à política tributária vigente, que não vislumbra a existência de um tributo eminentemente metropolitano, que leve em conta a característica majestosa dos problemas metropolitanos, que crescem em progressão assustadora, bem como não redistribui os tributos arrecadados aos estados e municípios, de uma forma condizente com a realidade de seus problemas;
- fator político-administrativo: falta de coordenação e entrosamento dos governos municipais que compõem uma área metropolitana. Cabe neste caso uma crítica à Lei Orgânica dos Municípios, que estabelece uma saudável diretriz de autonomia municipal, mas não coibe seu uso excessivo, principalmente quando interesses locais sobrepõem-se aos interesses regionais.

No Brasil, procurando superar alguns desses fatores agravantes, o governo federal, através da Lei Complementar n. 14 , de 8 de junho de 1973 , não só estabeleceu as regiões metropolitanas, como também procurou incentivar os municípios pertencentes a essas regiões, através de facilidades em financiamentos, a cooperarem no planejamento integrado e na execução de serviços comuns, reputados de interesse metropolitano, entre os quais, incluem-se: saneamento básico, notadamente abastecimento de água e rede de esgotos e serviço de limpeza pública; e aproveitamento dos recursos hídricos e controle de poluição ambiental, na forma que dispuser a lei federal.

Acertadamente, a Lei Complementar n. 14 indica o controle da poluição ambiental e, portanto, o controle da poluição do ar, como um serviço comum aos municípios que integram uma região metropolitana. Em base a esta lei, e a outras que se seguiram 
em nível estadual, relacionadas com o problema ambiental, no Estado de São Paulo, a Região Metropolitana de São Paulo - RMSP, desde 1973, vem sendo tratada, especialmente, no que diz respeito à poluição do ar, como uma verdadeira bacia aérea, definida legalmente como Região de Controle de Qualidade de Ar-1 - RCRA-1.

\section{A Região Metropolitana de São Paulo - RMSP}

\section{Características gerais}

A RMSP é composta por 37 municípios, e nela estavam concentrados, em 1980, 12.578 .145 habitantes, cerca de $50 \%$ da população do Estado, e $11 \%$ da nacional. Nesta área de $7.951 \mathrm{Km}^{2}$, inferior a 3,5\% da área do Estado e a 0,1\% do país, concentram-se $31 \%$ das inversões de capital, $36 \%$ e $41 \%$ do emprego e da renda industriais nacionais, respectivamente. A renda anual, por habitante, na RMSP, anda ao redor de US\$ 3,4 mil, e seu produto interno bruto gira em torno de US\$ 42,5 bilhões anuais.

Cerca de $70 \%$ da populaçã̃o está concentrada no Município de São Paulo, 20\% nos municípios de Osasco, Guarulhos e municípios da Região Sudeste (Santo André, São Bernardo do Campo, São Caetano do Sul, Mauá, Diadema, Ribeirão Pires e Rio Grande da Serra), restando aos demais 27 municípios apenas 10\% dos habitantes da RMSP. Este quadro de concentração pode também ser sentido nas receitas públicas e no número de empregados, onde $95 \%$ das mesmas são absorvidas e $95 \%$ dos mesmos estão concentrados, respectivamente pelos dez municípios citados. Durante a década de 70 a taxa de crescimento habitacional na RMSP foi em torno de $4,5 \%$ ao ano, enquanto que a do Estado foi de $2,9 \%$ e a do Brasil de $2,5 \%$.

Comparativamente, as características topográficas e meteorológicas da RMSP são favoráveis para a dispersão dos poluentes atmosféricos. Cumpre ressaltar que durante os meses de inverno, devido a ocorrência de um elevado grau de calmarias e a presença de vários tipos de inversões térmicas, as condições de dispersão são pioradas. A precipitação pluviométrica ocorre com maior freqüência nos meses de verão e os ventos predominantes têm direção susudeste: das áreas mais industrializadas para as áreas mais povoadas.

\section{Fontes de poluição do ar}

$\mathrm{Na}$ figura 1 estão apresentadas as principais fontes de poluição do ar na RMSP e os principais poluentes emitidos.

\section{Recursos institucionais e legais disponíveis}

Desde 1975, por delegação do governo do Estado de São Paulo, o controle da poluição do ar no Estado vem sendo desenvolvido de uma forma concentrada pela Companhia de Tecnologia de SaneaFigura 1 - Inventário das emissões de poluição do ar da RMSP - Cetesb
Dezembro 1978

\begin{tabular}{|c|c|c|c|c|c|c|c|c|c|c|}
\hline \multirow[b]{2}{*}{ Fontes } & \multicolumn{2}{|c|}{$\begin{array}{l}\text { Material Parti- } \\
\text { culado (MP) }\end{array}$} & \multicolumn{2}{|c|}{$\mathrm{SO}_{\mathrm{x}}$} & \multicolumn{2}{|c|}{$\mathrm{CO}$} & \multicolumn{2}{|c|}{$\mathrm{NO}_{x}$} & \multicolumn{2}{|c|}{$\mathrm{HC}$} \\
\hline & Ton/dia & $\%$ & Ton/dia & $\%$ & Ton/dia & $\%$ & Ton/dia & $\%$ & Ton/dia & $\%$ \\
\hline $\begin{array}{l}\text { Processos e ope- } \\
\text { rações industriais }\end{array}$ & 399 & 72,28 & 18 & 2,63 & 86 & 1,63 & - & - & 127 & 15,28 \\
\hline $\begin{array}{l}\text { Queima de com- } \\
\text { bustível em fontes } \\
\text { estacionárias }\end{array}$ & 28 & 5,07 & 541 & 79,09 & 19 & 0,36 & 62 & 14,76 & 9 & 1,08 \\
\hline Veículos a diesel & 13 & 2,36 & 82 & 11,99 & 195 & 3,70 & 158 & 37,62 & 33 & 3,97 \\
\hline Veículos à gasolina & 29 & 5,25 & 42 & 6,14 & 4.846 & 92,02 & 193 & 45,95 & 596 & 71,72 \\
\hline $\begin{array}{l}\text { Queima de resíduo } \\
\text { sólido }\end{array}$ & 32 & 5,80 & 1 & 0,15 & 120 & 2,28 & 7 & 1,67 & 39 & 4,69 \\
\hline Outras $^{*}$ & 51 & 9,24 & - & - & - & - & - & - & 27 & 3,25 \\
\hline Total & 552 & 100 & 684 & 100 & 5.266 & 100 & 420 & 100 & 831 & 100 \\
\hline
\end{tabular}

* Comercialização de produtos voláteis; poeiras fugitivas (tráfego em ruas sem asfalto, construção civil e obras de pavimentação). 
mento Ambiental - Cetesb, empresa de economia mista, vinculada à Secretaria de Obras e do Meio Ambiente - SOMA, e que tem como acionista majoritário o governo do Estado de São Paulo. Na área de avaliação e controle da poluição do ar na RMSP, a Cetesb dispunha, em março de 1983, de 260 funcionários, dos quais $70 \%$ profissionais de nível universitário. Em 1982, o custo direto das ações desta área atingiu $\mathrm{Cr} \$ 1,3$ bilhão. A Companhia dispunha de laboratórios e equipamentos suficientes para o desenvolvimento de seu programa de controle da poluição do ar, destacando-se o Sistema Telemétrico de Monitoramento do Ar da RMSP (25 estações), dois laboratórios volantes, um laboratório para medição de emissões de veículos, inclusive de veículos à álcool, um laboratório de engenharia do ar, as equipes de amostragem de chaminés, e os laboratórios de análises químicas do ar.

A ação de controle da poluição ambiental no Estado e, portanto, na RMSP, está baseada na Lei n. 997, de 31 de maio de 1976, alterada nos seus artigos $7^{\circ}$ e $8^{\circ}$ pela Lei . $^{\circ} 1.874$, de 8 de dezembro de 1978. Essas leis estão regulamentadas pelo Decreto $n$. 8.468 , de 8 de setembro de 1976 , alterado e acrescido pelos decretos n. 10.299 , de 29 de agosto de 1977; n: 10.755, de 22 de novembro de 1977; n. 11.720 , de 16 de junho de $1978 ; n$. 12.045 , de 8 de agosto de 1978; $n$. 15.425, de 23 de julho de 1980; e n. 16.266, de 2 de dezembro de 1980 .

Existem em âmbito estadual três outras leis específicas para a RMSP e que complementam a legislação referida anteriormente, principalmente no que diz respeito à proteção ambiental através da definição do uso do solo. Tratam-se das leis n: 898, de 18 de dezembro de 1975 e n. 1.172 , de 17 de novembro de 1976, regulamentadas pelo Decreto n. 9.714 , de 19 de abril de 1977, e que visam a proteção dos mananciais de água da RMSP, e da Lei $n^{\circ}$ 1.817, de 27 de outubro de 1978, regulamentada pelo Decreto $n^{\circ}$ 13.095, de 5 de janeiro de 1979, que estabelece os objetivos e as diretrizes para o desenvolvimento metropolitano e disciplina o zoneamento industrial na RMSP.

A legislação mencionada é bastante rigorosa, abrangente e de aplicação relativamente simples, estando adequada para a solução do problema atual de poluição ambiental no Estado de São Paulo.

Em geral, exceto no que diz respeito à aplicação da penalidade de interdição, essa legislação é apoiada pela Legislação Federal existente, em especial a Lei n. 6.939, de 31 de agosto de 1981, e seu regulamento decretado em 3 de junho de 1983. Esta lei federal centraliza erradamente o poder de suspensão de uma atividade poluidora, por mais de trinta dias, qualquer que seja o tipo, estabelecendo co- mo competência exclusiva do presidente da República.

\section{O Plano de Controle de Poluição do Ar na RMSP}

\section{Objetivos}

O objetivo básico do Plano de Controle de Poluição do Ar era proporcionar à população do Estado de São Paulo uma qualidade de ar que, pelo menos, não oferecesse risco à sua saúde. Esta qualidade do ar,.está definida, atualmente, em função dos poluentes mais importantes, através de padrões de qualidade do ar estabelecidos na legislação estadual e que constam da figura 2.

Dois outros objetivos complementares, que independem dos padrões de qualidade do ar, foram fixados e estão previstos na legislação vigente: a implantação de um plano de ação de emergência, visando proteger a população de determinadas áreas contra episódios agudos de poluição do ar; e a implantação de um sistema operativo de atendimento imediato de reclamações da população de determinadas áreas contra a poluição do ar provocada por fontes estacionadas mal-localizadas.

No caso do plano de ação de emergência, foram estabelecidas em lei as chamadas concentrações de emergência, acima das quais a saúde pública estará sob perigo eminente lestado de calamidade pública). Foram estabelecidas concentrações de emergência para os mesmos poluentes para os quais foram estabelecidos padrões de qualidade do ar. $\mathrm{Na}$ figura 3 estão apresentadas as concentrações de atenção, alerta e emergência, ressaltando que ao ser atingido um determinado nível de atenção, alerta ou emergência, para o que é necessário, não só que uma das concentrações da figura 3 seja ultrapassada, mas, também que, concomitantemente, as condições meteorológicas sejam desfavoráveis para a dispersão dos poluentes nas 24 horas subseqüentes, são impostas uma série de restrições sobre as atividades poluidoras na área atingida. Em 1976, quarenta grandes indústrias dos municípios de Santo André e São Caetano tiveram suas operações e processos poluidores paralizados por 18 horas, quando ocorreu na região o nível de alerta pelo produto (dióxido de enxofre $x$ partículas em suspensão).

\section{Diretrizes}

As ações que foram desenvolvidas visando atingir os objetivos descritos seguiram as seguintes diretrizes:

- as ações de controle deviam ser amplamente divulgadas, através de programas e campanhas 
Figura 2 - Padrões de qualidade do ar estabelecidos para o Estado de São Paulo (Decreto n. 8.468 , de 8 de setembro de 1976)

\begin{tabular}{|c|c|c|c|}
\hline \multirow{2}{*}{ Poluentes } & \multicolumn{2}{|c|}{ Padrões de qualidade do ar } & \multirow[b]{2}{*}{$\begin{array}{l}\text { Método de amostragem e } \\
\text { análise }\end{array}$} \\
\hline & $\begin{array}{l}\text { Concentração } \\
\qquad \mu \mathrm{g} / \mathrm{m}^{3}{ }^{*}\end{array}$ & $\begin{array}{l}\text { Tempo de } \\
\text { amostragem }\end{array}$ & \\
\hline \multirow[t]{2}{*}{$\begin{array}{l}\text { Partículas em } \\
\text { suspensão }\end{array}$} & 80 & $\begin{array}{l}\text { Média geométrica } \\
\text { anual }\end{array}$ & \multirow{2}{*}{$\begin{array}{l}\text { Média de amostrador } \\
\text { de grandes volumes ou } \\
\text { equivalente }\end{array}$} \\
\hline & $240^{* *}$ & $\begin{array}{l}\text { Média de } 24 \text { horas } \\
\text { consecutivas }\end{array}$ & \\
\hline \multirow{2}{*}{ Dióxido de enxofre } & 80 & $\begin{array}{l}\text { Média aritmética } \\
\text { anual }\end{array}$ & \multirow{2}{*}{$\begin{array}{l}\text { Método de pararosalina } \\
\text { ou equivalente }\end{array}$} \\
\hline & $365^{* *}$ & $\begin{array}{l}\text { Média de } 24 \text { horas } \\
\text { consecutivas }\end{array}$ & \\
\hline \multirow[t]{2}{*}{ Monóxido de carbono } & $10.000^{* *}$ & $\begin{array}{l}\text { Máxima média de } \\
8 \text { horas consecutivas }\end{array}$ & \multirow{2}{*}{$\begin{array}{l}\text { Método de absorção } \\
\text { de radiação infravermelho } \\
\text { não-dispersivo ou } \\
\text { equivalente }\end{array}$} \\
\hline & $40.000^{* *}$ & $\begin{array}{l}\text { Máxima média de } \\
1 \text { hora }\end{array}$ & \\
\hline $\begin{array}{l}\text { Oxidantes } \\
\text { fotoquímicos }\end{array}$ & $160^{*}$ & $\begin{array}{l}\text { Máxima média de } \\
1 \text { hora }\end{array}$ & $\begin{array}{l}\text { Método de luminescência } \\
\text { química ou equivalente }\end{array}$ \\
\hline
\end{tabular}

* concentração em microgramas por metro cúbico $\left(\mu \mathrm{g} / \mathrm{m}^{3}\right)$

** concentrações que não podem ser ultrapassadas mais de uma vez por ano.

Figura 3 - Concentrações dos niveis de atenção, alerta e emergência do Plano de Ação de Emergência para Episódios Críticos de Poluicão do Ar.

(Decreto n. 8.468, de 8 de setembro de 1976).

\begin{tabular}{l|r|r|r}
\hline \multirow{2}{*}{ Poluentes } & \multicolumn{3}{|c}{ Niveis } \\
\cline { 2 - 4 } & Atenção & Alerta & Emergência \\
\hline $\begin{array}{l}\text { Dióxido de enxofre }\left(\mathrm{SO}_{2} \text { ) }\right. \\
\text { (média de 24 horas) }\end{array}$ & $80 \mu \mathrm{g} / \mathrm{m}^{3}$ & $-1.600 \mu \mathrm{g} / \mathrm{m}^{3}$ & $2.100 \mu \mathrm{g} / \mathrm{m}^{3}$ \\
\hline $\begin{array}{l}\text { Material particulado (MP) } \\
\text { (média de 24 horas) }\end{array}$ & $375 \mu \mathrm{g} / \mathrm{m}^{3}$ & $625 \mu \mathrm{g} / \mathrm{m}^{3}$ & $875 \mu \mathrm{g} / \mathrm{m}^{3}$ \\
\hline $\begin{array}{l}\text { Produto (MPSO) } \\
\text { (média de 24 horas) }\end{array}$ & $65 \times 10^{3}$ & $261 \times 10^{3}$ & $393 \times 10^{3}$ \\
\hline $\begin{array}{l}\text { Monóxido de carbono (CO) } \\
\text { (média de 8 horas) }\end{array}$ & $15 \mathrm{ppm}$ & $30 \mathrm{ppm}$ & $45 \mathrm{ppm}$ \\
\hline $\begin{array}{l}\text { Oxidantes fotoquímicos } \\
\text { (expresso em } \mathrm{O}_{3} \text { ) } \\
\text { (média de } 1 \text { hora) }\end{array}$ & $200 \mu \mathrm{g} / \mathrm{m}^{3}$ & $800 \mu \mathrm{g} / \mathrm{m}^{3}$ & $1.200 \mu \mathrm{g} / \mathrm{m}^{3}$ \\
\hline
\end{tabular}

educativas, ou mesmo através dos órgãos de imprensa, procurando criar uma consciência adequada junto à população sobre o problema de poluição do ar, suas causas, seus efeitos e as medidas que estão sendo adotadas pelo governo e pelos responsáveis pelas atividades poluidoras;

- nos casos de poluição do ar em que houvesse manifestação da população, a mesma deveria ser convidada a participar do processo de equacionamento e solução do problema, auxiliando inclusive o organismo de controle na detecção de agentes poluidores incomodativos;

- as atividades que visavam o controle da poluição do ar deveriam ser desencadeadas com apoio na mais desenvolvida tecnologia,

- as ações que visavam o controle das fontes de poluição do ar não deveriam ser meramente coercitivas, mas deveriam ser acompanhadas de todo apoio tecnológico do órgão de controle, que deveriam, inclusive, catalizar eficientes meios de financiamento para os sistemas de controle de poluição do ar; 
- a iniciativa privada deveria ser estimulada no desenvolvimento de projetos, fabricação e instalação de sistemas de controle de poluição do ar;

- nas regiões ou áreas consideradas como saturadas (regiões ou áreas críticas) em termos de poluição do ar dever-se-ia: desincentivar a implantação de indústrias e outras atividades com maior potencial de ação poluidora; disciplinar a ampliação de estabelecimentos industriais e outras atividades existentes, de forma que sua expansão não aumente a poluição do ar e incentivar a transferência, para fora das cidades, de fábricas e atividades altamente poluidoras, já em funcionamento:

- sempre que não fosse possível o correlacionamento entre as emissões de uma ou mais fontes de poluição do ar e a qualidade do ar resultante, o controle das emissões deveria ser baseado no critério da "melhor tecnologia prática disponível" para cada caso;

- exceto nos casos de perigo eminente à saúde pública, os prazos a serem estabelecidos para a solução dos problemas de poluição do ar, deveriam ser os mais curtos, tecnicamente exequíveis, e deveriam levar em consideração: prazo para apresentação de planos, projetos e cronogramas, prazo para construção ou fabricação de equipamentos poluidores, se for o caso, prazo para instalação do sistema, prazo para teste ou avaliação do sistema.

\section{Estratégias}

\section{Considerações gerais}

A legislação estadual de meio ambiente dividiu o território do Estado de São Paulo em onze regiões de controle de qualidade do ar - RCQA (bacias aéreas), que atualmente coincidem com as onze regiões administrativas do Estado, sendo a $\operatorname{RCQA}^{1}$, a Região da Grande São Paulo. A legislação permite que estas regiões sejam subdivididas em sub-regiões, de acordo principalmente com parâmetros topográficos e meteorológicos. Também no decreto de regulamentação da Lei Estadual n. 997, de 31 de maio de 1976, está definido o conceito de saturação: considera-se uma região ou sub-região saturada, em termos de poluição do ar, quando qualquer um dos padrões de qualidade do ar estiver nela ultrapassado, ou seja, quando a concentração aferida em qualquer das estações medidoras ou estações de amostragem, nela localizadas, exceder, pelo menos, uma das concentrações especificadas como padrões de qualidade do ar.

Para efeito de aplicação das estratégias de controle, a Região da Grande São Paulo/RCQA-1 foi considerada prioritária, em 1977, em função dos dados disponíveis de qualidade do ar; das estimativas de emissão e de alguns outros indicadores, como número de veículos automotores em circulação; do número de reclamações da população; da densidade industrial e tendências de industrialização e urbanização. Tambẽm em função dos dados de qualidade do ar a RCQA-1 foi considerada saturada.

Tendo em vista a saturação da Região da Grande São Paulo, a partir de 1977 iniciou-se um rigoroso programa preventivo da poluição do ar, utilizandose como instrumento o sistema de licenciamento previsto na legislação. De outubro de 1976 até outubro de 1982, a Cetesb emitiu 18.466 licenças de instalação, com ou sem exigências técnicas de controle, tendo negado cerca de $5 \%$ deste número, e emitiu 14.542 licenças de funcionamento, tendo sido desfavorável em $10 \%$ dos casos solicitados. As principais razões de pareceres negativos ou desfavoráveis foram: localização incompatível com o uso definido ou "existente" do solo; tipos de indústrias sem vocação metropolitana; tipo de indústrias que mesmo providas com a melhor tecnologia de controle continuavam a oferecer risco à saúde, segurança e bem-estar da população, etc.

\section{Estratégia básica}

Na figura 4 está apresentado o esquema da estratégia básica que foi adotada para controle da poluição do ar no Estado de São Paulo até março de 1983. Fundamentalmente, procura-se, em função dos dados de qualidade do ar existentes, do inventário das fontes existentes de poluição do ar e do crescimento que se estima ocorrer nas emissões pela instalação de novas fontes de poluição do ar, tendo em vista os padrões de qualidade de ar estabelecidos, determinar a redução necessária - RN, nas emissões existentes e nas futuras emissões dentro de um certo período de tempo. Obtendo-se a redução necessária, verifica-se se esta redução é possível, em função principalmente da melhor tecnologia disponível, e determina-se a redução obtível $\mathrm{RO}$, quer $\mathrm{RO}_{\mathrm{e}}$ para as fontes existentes, como $\mathrm{RO}_{\mathrm{n}}$ para as fontes novas. Comparando-se a RN com a RO obtém-se a redução de projeto, que conduz ao estabelecimento de: padrões de emissão que, segundo a legislação vigente: "como tais entendidas a intensidade, a concentração e as quantidades máximas de toda e qualquer forma de matéria ou energia, cujo lançamento ou liberação, nas águas, no ar ou no solo seja permitido"; padrões de condicionamento e projeto que, segundo a legislação vigente: "como tais entendidas as características e as condições de lançamento, ou liberação, de toda e qualquer forma de matéria ou energia, nas águas, no ar ou no solo, bem como as características de localização e de utilização das fontes de poluição. 
Figura 4 - Esquema de estratégia básica de controle de poluição do ar. (Cetesb/Diretoria de Tecnologia do Ar e de Ação Metropolitana (março 1975 - março 1983).

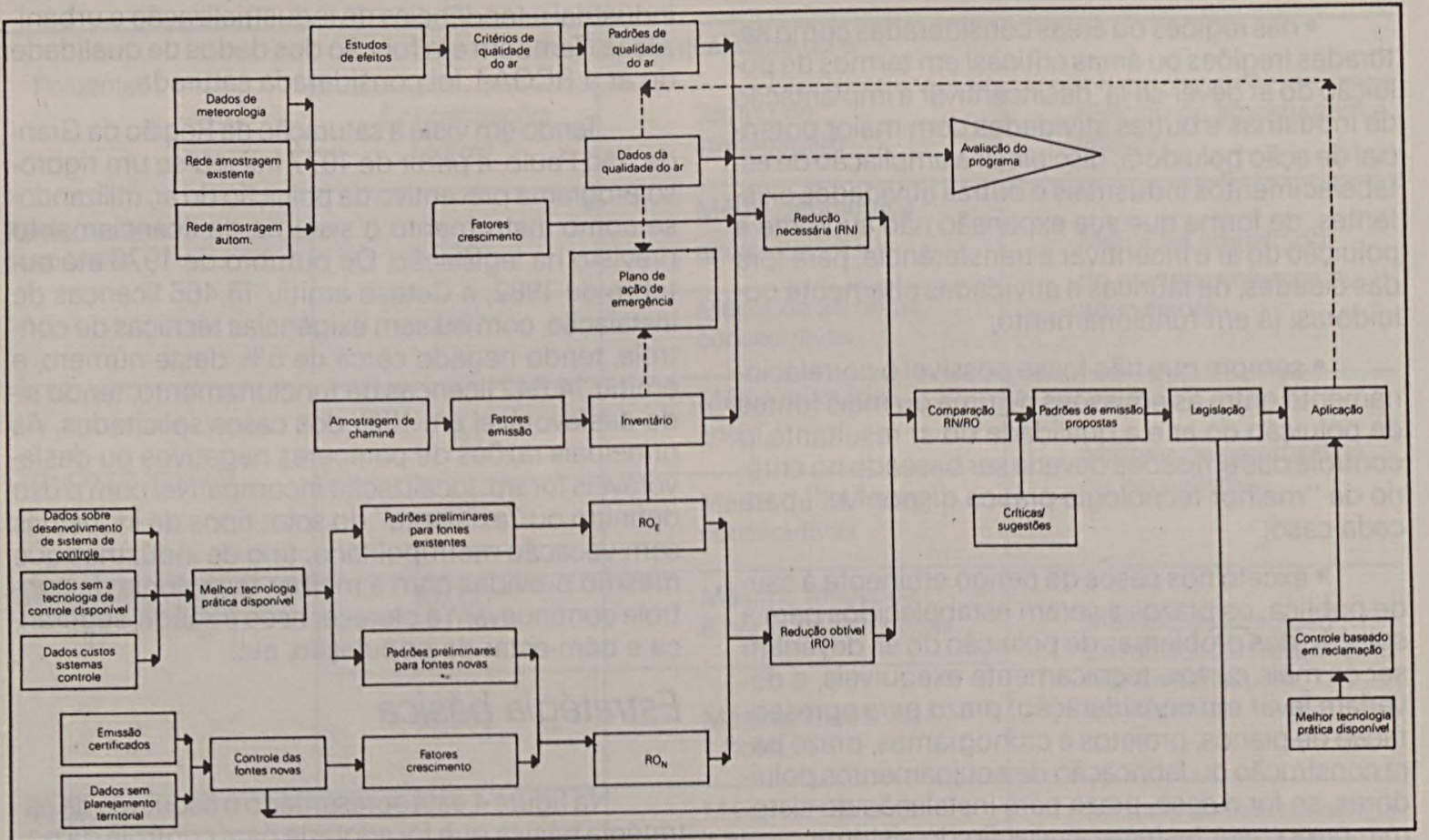

Cumpre ressaltar que uma série de padrões de emissão e de condicionamento e projeto foram estabelecidos sem levar em conta a estratégia básica mencionada, mas sim fatores de performance de equipamentos, melhor prática e, mesmo, evitar emissões desnecessárias. Como exemplo, pode-se citar os padrões de emissão estabelecidos para fumaça proveniente de fontes estacionárias de combustão e por veículos a óleo diesel (Escada de Ringelmann); proibição de queima de lixo ao ar livre; tipo de combustível a ser utilizado em áreas residenciais ou comerciais; utilização de sistemas de ventilação local exaustora elou chaminés para o lançamento de emissões poluidoras; padrões e normas de controles para emissões odoríferas.

\section{Controle de monóxido de carbono e oxidantes fotoquímicos}

Em base aos dados do inventário apresentado na figura 1, o controle de monóxido de carbono somente será eficaz se atingir os veículos à gasolina (92\% das emissões), e o controle dos oxidantes fotoquímicos, que são resultados de reações fotoquímicas na atmosfera entre componentes do ar atmosférico, óxidos de nitrogênio e hidrocarbonetos, também requer uma ação sobre os veículos à gasolina.
Os dados de qualidade do ar existentes mostram que desde 1976 as concentrações de monóxido de carbono ultrapassam o padrão de qualidade do ar durante mais do que $50 \%$ dos dias do ano. A figura 5 apresenta dados de concentrações de monóxido de carbono das estações do Sistema Telemétrico de Monitoramento da Cetesb, que começaram a funcionar em 1981 e estavam em plena operação até março de 1983.

Em 1977, a Cetesb realizou uma avaliação do grau de exposição de amostras populacionais de São Paulo ao monóxido de carbono e na figura 6 pode ser observado os resultados principais, onde uma porcentagem significativa de policiais não-fumantes que trabalham no centro da cidade de São Paulo apresentam índices de carboxihemoglobina acima do aceitável (até $2 \%$ de saturação).

Visando iniciar o controle de monóxido de carbono na RMSP, a Cetesb desencadeou uma série de estudos, alguns dos quais em conjunto com a própria indústria automobilística, tendo em 1977 solicitado aos órgãos competentes federais a distribuição permanente para os veículos à gasolina de uma mistura carburante gasolinalálcool etílico (inicialmente em torno de $12 \%$ ). Atendida a sugestão, já em 1977 ocorreu uma queda média de cerca de $23 \%$ na 
Figura 5 - Número de vezes que foram ultrapassados os padrões de CO, e concentrações de monóxido de carbono, em ppm, encontradas nas estações do Sistema Telemétrico de Monitoramento da Cetesb ño ano de 1981 na Região Metropolitana de São Paulo e no Município de Cubatão.

\begin{tabular}{|c|c|c|c|c|c|c|c|}
\hline \multirow{4}{*}{ Estação } & \multicolumn{3}{|c|}{ Ultrapassagens } & \multirow{2}{*}{\multicolumn{2}{|c|}{1 hora }} & \multirow{2}{*}{\multicolumn{2}{|c|}{8 horas }} \\
\hline & \multirow{2}{*}{\multicolumn{2}{|c|}{ PQAR }} & \multirow{3}{*}{\begin{tabular}{|c|} 
Nivel \\
de \\
atenção
\end{tabular}} & & & & \\
\hline & & & & \multirow[b]{2}{*}{$M_{1}$} & \multirow[b]{2}{*}{$M_{2}$} & \multirow[b]{2}{*}{$M_{1}$} & \multirow[b]{2}{*}{$M_{2}$} \\
\hline & 1h & $8 \mathrm{~h}$ & & & & & \\
\hline Parque D. Pedro & 1 & 17 & 4 & 43,2 & 29,8 & 20,1 & 17,1 \\
\hline Mooca & - & 10 & - & 26,5 & 23,0 & 15,0 & 14,9 \\
\hline Congonhas & - & 65 & 9 & 28,9 & 28,0 & 22,8 & 21,2 \\
\hline Cerqueira César & - & 52 & 7 & 28,6 & 26,0 & 17,8 & 17,4 \\
\hline Cubatão & - & 4 & 3 & 24,7 & 23,1 & 23,2 & 21,8 \\
\hline Juquitiba & - & - & - & 10,6 & 9,8 & 2,4 & 2,3 \\
\hline Praça do Correio & 7 & 274 & 98 & 42,5 & 39,0 & 26,7 & 26,6 \\
\hline
\end{tabular}

\section{Legenda}

PQAR - Padrão de Qualidade do Ar

PQAR 1 hora - 35ppm

PQAR 8 horas - 9ppm

Atenção - 15ppm (8h)

$\mathrm{M}_{1}$ - 1: máximo

$\mathrm{M}_{2}-2^{\circ}$. máximo concentração de monóxido de carbono na atmosfera da RMSP. A adição de álcool etílico na gasolina reduziu também, a partir de 1977, a quantidade adicionada de chumbo tetraetila, portanto, reduziu a emissão de compostos de chumbo na atmosfera, uma vez que o álcool tem propriedades antidetonantes.

Também foi definido, através dos estudos desenvolvidos, que a estratégia de controle a ser adotada deveria ser dirigida aos veículos novos (ainda não-comercializados) e para os veículos em circulação não seriam feitas exigências de controle. Esta decisão foi tomada em função da baixa eficiência esperada para um programa de controle baseado em regulagem obrigatória anual e do alto custo envolvido para adoção desta medida.

Para veículos novos, com a implantação do Laboratório de Testes de Veículos, no início de 1981, foi desenvolvido um programa de determinação das emissões de veículos nacionais e para o combustível nacional. Estes testes estão baseados no Ciclo CVS (Constant Volume Sampler). Em janeiro de 1983, a Cetesb elaborou um relatório (P.J. 3.1) - Desenvolvimento de Padrões de Emissão para Veículos Leves do Ciclo Otto/Primeira Fase, no qual foram apresentados os fatores de emissão obtidos para gasolina com $20 \%$ de álcool etílico, em veículos/modelos 1981, quais sejam: monóxido de carbono (CO)

Figura 6 - Avaliação do grau de exposição de amostras populacionais de São Paulo do monóxido de carbono (1977)

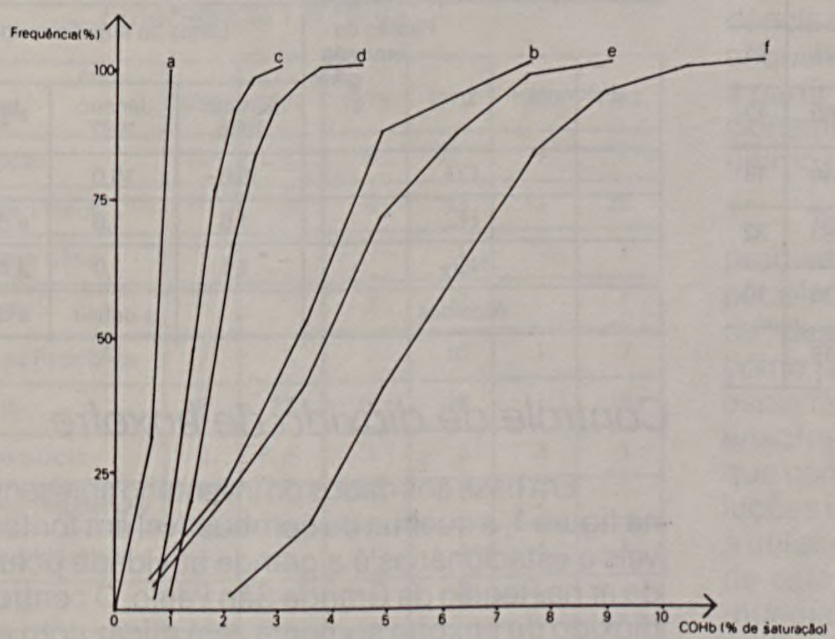

Frequencia percentual acumulada dos valores de $\mathrm{COHb}$ (\% de saturação) em fumantes e não-tumantes Legenda

a - grupo controle dos não-fumantes

b - grupo controle dos fumantes

c - empregados de transporte coletivo não-fumantes d - policiais não-fumantes

e - empregados de transporte coletivo fumantes

$f$-policiais fumantes 
- 36,8g/Km; hidrocarbonetos $(\mathrm{HC})-3,3 \mathrm{~g} / \mathrm{Km}$; ́xidos de nitrogênio $\left(\mathrm{NO}_{x}\right)-1,4 \mathrm{~g} / \mathrm{km}$.

Para veículos a álcool foram obtidos os seguintes valores: $\mathrm{CO}-18,5 \mathrm{~g} / \mathrm{km} ; \mathrm{HC}-0,9 \mathrm{~g} / \mathrm{km} ; \mathrm{NO}_{\mathrm{x}}$ $1,2 \mathrm{~g} / \mathrm{km}$.

Por estes dados pode ser observado que os veículos a álcool emitem cerca de $50 \%$ a menos de CO quando comparados com veículos à gasolina com $20 \%$ de álcool; o mesmo ocorre com a emissão de $\mathrm{HC}$ e com a de $\mathrm{NO}_{x}$, cerca de $73 \%$ e $14 \%$ a menos, respectivamente.

Com relação aos oxidantes fotoquímicos, que basicamente causam irritação à vista, danos à vegetação e aos produtos de borracha, pode-se observar na figura 7 um quadro que apresenta dados de oxidåntes fotoquímicos (expressos em ozone), medidos na RMSP, em 1981.

Figura 7 - Número de vezes que foram ultrapassados os padrões de oxidantes fotoquímicos e concentrações dos mesmos em ppb nas estações do Sistema Telemétrico de Monitoramento da Cetesb no ano de 1981 na RMSP e Cubatão

\begin{tabular}{|c|c|c|c|c|c|c|c|}
\hline \multirow{3}{*}{ Estação } & \multicolumn{3}{|c|}{ Ultrapassagens } & \multirow[b]{3}{*}{$M_{1}$} & \multirow[b]{3}{*}{$M_{2}$} & \multirow[b]{3}{*}{$\% R_{1}$} & \multirow[b]{3}{*}{$\% \mathrm{R}_{2}$} \\
\hline & \multicolumn{2}{|c|}{ Dias } & \multirow{2}{*}{\begin{tabular}{|l|} 
Vezes \\
PQAR
\end{tabular}} & & & & \\
\hline & PQAR & $\begin{array}{c}\text { Nivel } \\
\text { de } \\
\text { atenção }\end{array}$ & & & & & \\
\hline Parque D. Pedro* & 24 & 8 & 47 & 150 & 140 & 41 & 14 \\
\hline Mooca* & 41 & 19 & 93 & 226 & 207 & 60 & 42 \\
\hline Congonhas* & 8 & 4 & 11 & 164 & 146 & 44 & 18 \\
\hline Lapa* & 24 & 11 & 46 & 323 & 176 & 53 & 32 \\
\hline Cubatão & 24 & 3 & 40 & 2,33 & 133 & 38 & 10 \\
\hline Juquitiba* & 8 & 0 & 11 & 101 & 94 & 13 & - \\
\hline
\end{tabular}

- estações localizadas no Município de São Paulo

Legenda

PQAR - Padrão de Qualidade do $\mathrm{Ar}$

PQAR - 82ppb - $160 \mu \mathrm{g} / \mathrm{m}^{3}$

Atenção $-102 \mathrm{ppb}-200 \mu \mathrm{g} / \mathrm{m}^{3}$

$\% R_{1}$ - Redução em relaçăo ao PQAR (82ppb)

$\% R_{2}$ - Redução em relação ao padrão americano (120ppb)

$\mathrm{M}_{1}$ - $1^{\circ}$. máximo

$\mathrm{M}_{2}-2^{\circ}$ máximo

A Cetesb constatou também que os veículos a etanol emitem significativamente mais aldeídos que o veículo à gasolina, sendo o aumento médio de $441 \%$. Este aumento é preocupante uma vez que não se tem a caracterização definitiva sobre a quan- tidade e qualidade dos aldeídos presentes. É conveniente que se observe que as emissões de aldeídos estão presentes também nos veículos à gasolina, além de existir a emissão de compostos de chumbo, substância altamente tóxica, os quais não estão presentes nas emissões do veículo a etanol. A Cetesb, durante o período de julho de 1980 a junho de 1981, determinou concentração de aldeídos na Praça do Correio, no Parque D. Pedro, na Mooca e no Aeroporto de Congonhas, tendo-se encontrado valores máximos (expressos como formaldeído) de até $159 \mathrm{ppb}$ no Aeroporto de Congonhas. Na Praça do Correio, onde foram encontradas as maiores concentrações médias de 36 a 58 ppb, verificou-se que estes concentrações correlacionam-se significativamente com as de monóxido de carbono, ficando sugerida a prevalência de aldeídos primários (derivados diretamente das fontes) e não aldeídos secundários (formados na atmosfera por reações fotoquímicas). Estudos de correlação sugeriram que isto também ocorre no Aeroporto de Congonhas.

O equacionamento e a solução do problema de oxidantes fotoquímicos e aldeídos estão intimamente ligados com os do monóxido de carbono, e o relatório (P.J. 3.1), elaborado pela Cetesb em janeiro de 1983, sugeriu padrões de emissão para veículos a alcool e à gasolina com $20 \%$ de álcool, que estão apresentados na figura 8.

Figura 8 - Padrões de emissão para veículos a alcool e à gasolina com $20 \%$ de álcool

\begin{tabular}{cc|c|c|c}
\hline \multirow{2}{*}{ Poluente } & $\begin{array}{c}\text { Padrão de } \\
\text { emissão } \\
\text { g/km }\end{array}$ & \multicolumn{3}{|c}{ Datas de atendimento } \\
\cline { 3 - 5 } & & $\begin{array}{c}\text { Janeiro } \\
1985\end{array}$ & $\begin{array}{c}\text { Janeiro } \\
1987\end{array}$ & $\begin{array}{c}\text { Janeiro } \\
1990\end{array}$ \\
\hline CO & 15,0 & 10,0 & 5,0 \\
\hline HC & 1,5 & 1,0 & a definir \\
\hline NOX & 1,4 & 1,0 & a definir \\
\hline Aldeídos & - & a definir & a definir \\
\hline
\end{tabular}

\section{Controle de dióxido de enxofre}

Em base aos dados do inventário apresentados na figura 1 , a queima de combustível em fontes móveis e estacionárias é a grande atividade poluidora do ar na Região da Grande São Paulo. O controle de dióxido de enxofre somente será eficaz com a adoção de combustíveis com baixo teor de enxofre, ou utilização de alternativa energética não-poluidora como gás combustível e energia elétrica.

A Cetesb vem determinando sistematicamente as concentraç̃̃es de dióxido de enxofre $\left(\mathrm{SO}^{2}\right)$ na RMSP, desde 1973, através de quatorze estações de 
amostragem do tipo OPS/OMS, cuja maioria deixou de operar em dezembro de 1981, com a entrada em funcionamento da Rede Telemétrica de Monitoramento. Através desses dados pode ser constatado que em todos os locais, com excessão da estação localizada no Bairro de Pinheiros no Município de São Paulo, está ultrapassado o padrão anual de qualidade de ar $\left(80 \mathrm{mg} / \mathrm{m}^{3}\right)$, para dióxido de enxofre. $\mathrm{Na}$ Região de Capuava, entre os municípios de Mauá e Santo André, ocorreram concentrações diárias nos anos de 1974, 1976 e mais recentemente 1979, em torno de $1.300 \mathrm{mg} / \mathrm{m}^{3}$, ou seja, ultrapassando em mais de três vezes o padrão diário de qualidade do $\operatorname{ar}\left(365 \mathrm{mg} / \mathrm{m}^{3}\right)$.

Na figura 9 está apresentado um quadro contendo o produto das concentrações de material particulado e dióxido de enxofre, em termos do número de vezes que foi ultrapassado o nível de atenção do Plano de Ação de Emergência. Este produto é um parâmetro que procura levar em consideração o efeito sinergético que ocorre em termos de saúde, quando os dois poluentes se apresentam simultaneamente no ar atmosférico. Através deste quadro pode-se verificar que predominam as ultrapassagens no Bairro de Tatuapé, no Município de São Paulo, onde também as concentrações de material particulado são elevadas.

Figura 9 - Número de vezes que o produto das concentrações de material particulado e dióxido de enxofre ultrapassaram o nivel de atenção no Plano de Ação de Emergência (1976-1981)

\begin{tabular}{|l|r|r|r|r|r|r|}
\hline Estações Anos & 1976 & 1977 & 1978 & 1979 & 1980 & 1981 \\
\hline Aclimação & 13 & 8 & 9 & \multicolumn{1}{c|}{21} & 9 & 7 \\
\hline Campos Eliseos & 11 & 9 & 6 & 43 & 13 & 25 \\
\hline Cerqueira César & & & & 1 & & 1 \\
\hline Moema & & & 2 & 7 & & 1 \\
\hline Praça da República & 7 & 3 & 2 & 16 & 1 & 7 \\
\hline Tatuapé & 18 & 22 & 17 & 28 & 17 & 19 \\
\hline Vila Anastácio & 2 & 2 & 1 & 3 & 3 & 1 \\
\hline Capuava Residencial & & & & & 2 & \\
\hline Capuava Industrial & 4 & & 1 & 4 & 4 & 4 \\
\hline Guarulhos & 1 & & 2 & 9 & 4 & 2 \\
\hline Osasco & & & & 1 & & \\
\hline São Caetano do Sul & 8 & 1 & 1 & 7 & 4 & 3 \\
\hline Santo André & 16 & & 2 & 4 & 2 & \\
\hline Pinheiros & & & 1 & 2 & & \\
\hline Total por ano & 80 & 45 & 44 & 146 & 59 & 70 \\
\hline
\end{tabular}

A análise e interpretação dos dados de dióxido de enxofre obtidos pela Cetesb, de 1973 a 1981, levaram às seguintes sugestões:

- nos bairros do Município de São Paulo, como Campos Elíseos e Cerqueira César, onde as principais fontes de dióxido de enxofre eram os veículos a diesel, a tendência do problema era crescente desde 1973, acompanhando de certa forma o crescimento do número de veículos a diesel, principalmente ônibus, para atendimento à população crescente;

- nos bairros de São Paulo, como Tatuapé e Vila Anastácia, onde as fontes de poluição do ar por dióxido de enxofre eram os veículos a diesel e a queima de combustível pelas indústrias, a tendência do problema é estacionária desde 1973. Nestes bairros, praticamente, está estagnado o crescimento industrial, e os dados sugerem inclusive uma possível redução desta atividade, que compensaria o crescimento dos veículos a diesel;

- em determinados municípios da RMSP, cujo processo de industrialização é mais recente, como Osasco e Guarulhos, quando comparado com municípios do $\mathrm{ABC}$, a tendência era estacionária, porém a partir de 1979/1980 começou a ser crescente em termos de dióxido de enxofre;

- nos municípios do ABC, como Santo André e São Caetano do Sul, e na área de Capuava, áreas tradicionalmente industriais, a tendência é decrescente. Cabe diferenciar que na área de Capuava a tendência decrescente torna-se estável a partir de 1976, enquanto que nos outros dois locais torna-se visível a partir de 1979, sugerindo esta queda um correlacionamento com a queda da produção industrial nos últimos anos.

Todos esses dados mostraram que existia um problema grave de dióxido de enxofre na RMSP, especialmente na chamada "área urbanizada conurbada" desta região, e que o principal fator de poluição, como já indicađo, é a queima de óleo combustível, especialmente o BPF, que contém mais de $5 \%$ de enxofre na composição, contrastando com o BTE que contém em torno de $1 \%$. Portanto, uma das soluções imediatas para a solução do problema, seria a utilização de óleo BTE, porém a sua disponibilidade está intimamente relacionada com o mercado mundial de petróleo de baixo teor de enxofre, e com a situação do balanço de pagamentos do país. A médio prazo a dessulfurização dos derivados de petróleo nas refinarias da Petrobrás, seria uma alternativa interessante no contexto saúde-economia.

A Cetesb gestionou junto aos órgãos federais competentes, desde 1976, para que fosse distribuí- 
do cada vez mais na RMSP, óleo BTE. Estas gestões conduziram a duas medidas concretas:

- distribuição constante, durante todo o ano, de óleo BTE (cerca de $40 \%$ mais caro) para os grandes consumidores industriais, localizados na área de Capuava. As reduções de dióxido de enxofre na atmosfera daquela área atingiram valores de $30 \%$ depois da adoção da medida a partir de julho de 1976;

- distribuição durante os quatro meses de inverno, nos quais as condições de dispersão dos poluentes são as mais desfavoráveis, de maiores quantidades de óleo BTE. Normalmente na RMSP são distribuídas, aproximadamente, de forma constante, $50.000 \mathrm{t} / \mathrm{m}$ de óleo BTE de um total de $300.000 \mathrm{t} / \mathrm{m}$ de óleo combustível. Durante o inverno de 1976 foram distribuídos cerca de $80.000 \mathrm{t} / \mathrm{m}$ e de $1977 \mathrm{em}$ diante cerca de $110.000 \mathrm{t} / \mathrm{m}$. Até 1981 , as indústrias consumiam este óleo em forma de colaboração; a partir de 1982 o consumo foi imposto a cerca de oitenta grandes consumidores que, inclusive, por decisão do Conselho Nacional do Petróleo - CNP, estavam proibidos de receber outro tipo de óleo, que não o BTE.

Através destas medidas houve uma redução das altas concentrações, minimizando riscos de efeitos agudos à saúde da população nos meses de inverno. Na figura 10, estão apresentadas as concentrações médias anuais de dióxido de enxofre e material particulado, encontradas na estação de amostragem localizada na área de Capuava.
Tendo em vista a aplicação da estratégia básica, em janeiro de 1982, a Cetesb, após tentar sem sucesso, junto aos órgãos governamentais federais competentes, a substituição do óleo BPF por BTE desencadeou o Programa de Controle de Poluição do Ar por Dióxido de Enxofre na RMSP, que tem como objetivo específico, reduzir até dezembro de 1985 a emissão de $80 \%$ deste poluente, proveniente da queima de óleo combustível BPF em várias atividades, principalmente industrial. O programa engloba 2.142 empresas que emitiam (1981) 587t/dia de dióxido de enxofre na atmosfera. As empresas foram autuadas para, no prazo de noventa dias, apresentar plano de controle, que visassem a redução de $80 \%$ das emissões, tendo sido estabelecido como padrão de emissão, $20 \mathrm{~kg}$ de dióxido de enxofre por tonelada de óleo consumido, tomando-se como base a cota de óleo aprovada em 1981 pelo CNP. Numa primeira fase (até julho/1982) foram autuadas 189 empresas (curva A) que emitiam $80 \%$ do total emitido; numa segunda fase (até dezembro/1982) foram autuadas 264 empresas (cota superior a 500t/ano) das 428 (curva B) que emitiam 15\% do total; as restantes 164 das 428 , e as 1.525 empresas que emitiam os restantes $5 \%$ do total (curva C) foram deixadas para uma terceira fase (julho/1983 a julho/1984). A expectativa da Cetesb, era de que $50 \%$ das empresas das curvas $\mathrm{A}$ e B solucionassem o problema através do uso de energia elétrica (mais de duzentas empresas até março de 1983 já tinham apresentado um plano ou solucionado o problema), e as demais utilizassem outra forma de energia elou equipamento de controle de dióxido de enxofre (lavagem alcalina ou equivalente).

Figura 10 - Concentrações médias anuais - Região de Capuava Industrial

MP

$\left(\mu \mathrm{g} / \mathrm{m}^{3}\right)$

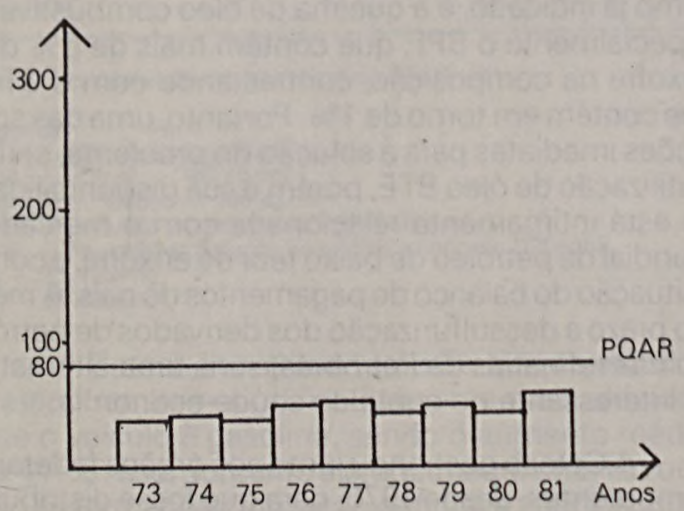

$\mathrm{SO}_{2}$

$\left(\mu \mathrm{g} / \mathrm{m}^{3}\right)$

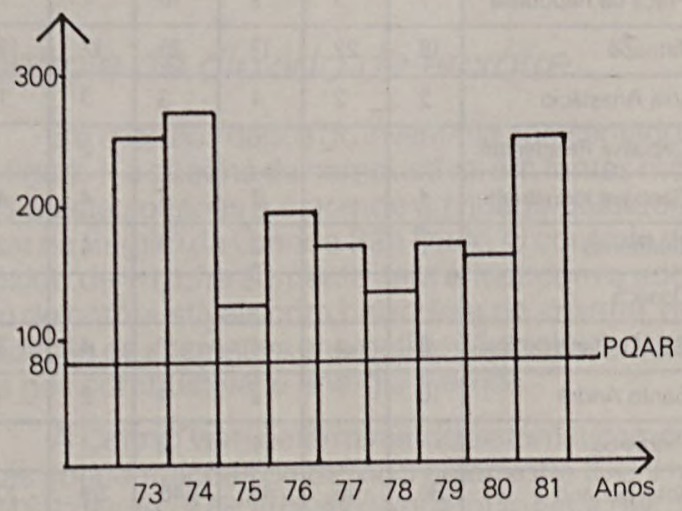


Paralelamente, a Cetesb vinha proibindo, através de seu sistema de licenciamento, a instalação de uma nova fonte ou a ampliação de uma fonte existente, que venha a emitir significativamente dióxido de enxofre na bacia aérea da Grande São Paulo. Estavam sendo permitidas a instalação ou ampliação de fontes que consomem até $500 t / a n o$ de óleo combustivel BPF, ou equivalente em poluição por dióxido de enxofre, nos municípios não-críticos da RMSP (todos com excessão de São Paulo, Osasco, GuaruIhos, Taboão da Serra, Santo André, São Caetano do Sul, São Bernardo do Campo, Diadema, Mauá, Ribeirão Pires e Rio Grande da Serral; estava liberado também a circulação de novos veículos a diesel. Vale a pena ressaltar que o CNP não estava emitindo nenhuma ordem para novas cotas ou aumento de cota de óleo combustível para qualquer tipo de empresa, inclusive que utilizassem ônibus ou caminhões a diesel, sem o parecer favorável da Cetesb.

\section{Controle do material particulado}

Desde 1973, a Cetesb vem avaliando sistematicamente as concentrações de material particulado (MP) na RMSP, através das estações de amostragem do tipo OPS/OMS. Através desses dados pode ser verificado que o padrão de qualidade do ar anual respectivo, está ultrapassado em algumas áreas da RMSP, especialmente nos bairros do Tatuapé, Campos Elíseos e Praça da República no Município de São Paulo, e na área central do Município de GuaruIhos. Estes mesmos dados mostram que as concentrações máximas diárias ocorridas em 1976 nas áreas centrais dos municípios de Santo André e São Caetano do Sul, ultrapassaram em quase três vezes o padrão diário de qualidade do ar $\left(240 \mathrm{mg} / \mathrm{m}^{3}\right)$ para material particulado, e que este padrão é ultrapassado em todas as estações de amostragem da RMSP com excessão de Capuava residencial.

Na figura 11 está apresentado um conjunto de gráficos que espelha um trabalho realizado pela Cetešb, em 1976, Avaliação de Efeitos da Poluição do Ar sobre a Saúde, através do Estudo da Mortalidade Diária da Grande São Paulo - 1973. Através deste conjunto de gráficos pode-se observar que no ano de 1973 na RMSP está sugerido que pelo menos uma das elevações acentuadas de mortalidade, çom pico máximo no dia $11^{\circ}$ de agosto está relacionada com a deterioração da qualidade do ar por dióxido de enxofre e material particulado. Neste episódio o aumento da mortalidade fez-se essencialmente às custas de pessoas idosas e portadoras de doenças do aparelho respiratório e do aparelho circulatório.

Na figura 12 também está apresentado um conjunto de gráficos que espelha um outro trabalho realizado pela Cetesb, em 1976, Avaliação de Efeitos
Agudos da Poluição do Ar sobre a Saúde, através do Estudo da Morbidade Diária em São Caetano do Sul - junho/1976 (estudo preliminar); através dos quais pode-se observar que no dia 23 de junho de 1976 , quando ocorreu estado de alerta por produto no município de São Caetano do Sul, houve um sensível aumento na procura de atendimento nos serviços médicos locais. Neste dia ocorreu a maior concentração diária de material particulado na RMSP, até março de 1983 , de $660 \mathrm{mg} / \mathrm{m}^{3}$ na estação de São Caetano do Sul.

Todos esses dados mostraram que existia um problema grave de material particulado na RMSP, e que o principal fator de poluição, conforme pode ser constatado na figura 1, é a atividade industrial, quer pelos processos e operações industriais, quer pela queima de óleo combustível.

Para o controle desse poluente, tendo em vista a estratégia básica mencionada anteriormente, a Cetesb, em 1979, aplicou um modelo matemático para a RMSP, que assume uma distribuição linear homogênea de redução das fontes emissoras e uma correlação linear entre a emissão e a concentração no ar atmosférico. O modelo utilizado está baseado na filosofia do modelo proporcional (ROLLBACK), que pode ser assim expressado:

$$
\begin{aligned}
& \mathrm{R}=\frac{\mathrm{Cmax} \times \mathrm{F} 1-\mathrm{P}}{\mathrm{Cmax} \times \mathrm{F} 1-\mathrm{B}} \times 100, \text { onde } \\
& \mathrm{R}=\begin{array}{l}
\text { porcentagem de redução necessária nas } \\
\text { emissões do poluente numa determina- } \\
\text { da região, }
\end{array}
\end{aligned}
$$

Cmax = a mais alta concentração do poluente da região,

$\mathrm{F} 1=$ fator de crescimento das emissões do poluente (novas fontes),

$\mathrm{P}=$ padrão de qualidade do ar do poluente,

$\mathrm{B}=$ concentração irredutível do poluente na região (background).

A aplicação do modelo levou à seguinte conclusão, que foi-utilizada para a elaboração dos padrões de emissão para os produtos e operações industriais que emitiam material particulado: os processos e operações industriais localizados na RMSP deverão reduzir em $78,5 \%$ suas emissões de material particulado, a fim de que as concentrações deste poluente caiam abaixo do padrão de qualidade do ar, e que somente após dez anos, com um crescimento de $5 \%$ ao ano das emissões dos novos processos e operações industriais, o padrão de qualidade do ar seja novamente ultrapassado.

Em base a esta redução necessária, e considerando a tecnologia de controle disponível para os diversos tipos de processos e operações industriais, 
Figura 11 - Gráficos do trabalho da Cetesb/1976: avaliação de efeitos da poluição do ar sobre a saúde, através do estudo da mortalidade diária da Grande São Paulo - 1973

Gráfico 1: Distribuição das concentrações médias diárias de dióxido de enxofre e de material particulado, no período de 25 de julho a 8 de agosto de 1973. (Fonte: Susan/Cetesb)

Gráfico 2: Distribuição dos óbitos diários na Grande São Paulo, no período de 25 de julho a 8 de agosto de 1973. (Fonte: Tabulação direta de mapas fornecidos pelo DEE)

Gráfico 3: Número diário de óbitos de pessoas com 65 e mais anos de idade, ocorridos na Grande São Paulo, no período de 25 de julho a 8 de agosto de 1973.

Gráfico 4: Número diário de óbitos por doenças do aparelho circulatório, ocorridos na Grande São Paulo, no período de 25 de julho a 8 de agosto de 1973.

Gráfico 5: Número diário de óbitos por doenças do aparelho respiratório, ocorridos na Grande São Paulo, no período de 25 de julho a 8 de agosto de 1973.
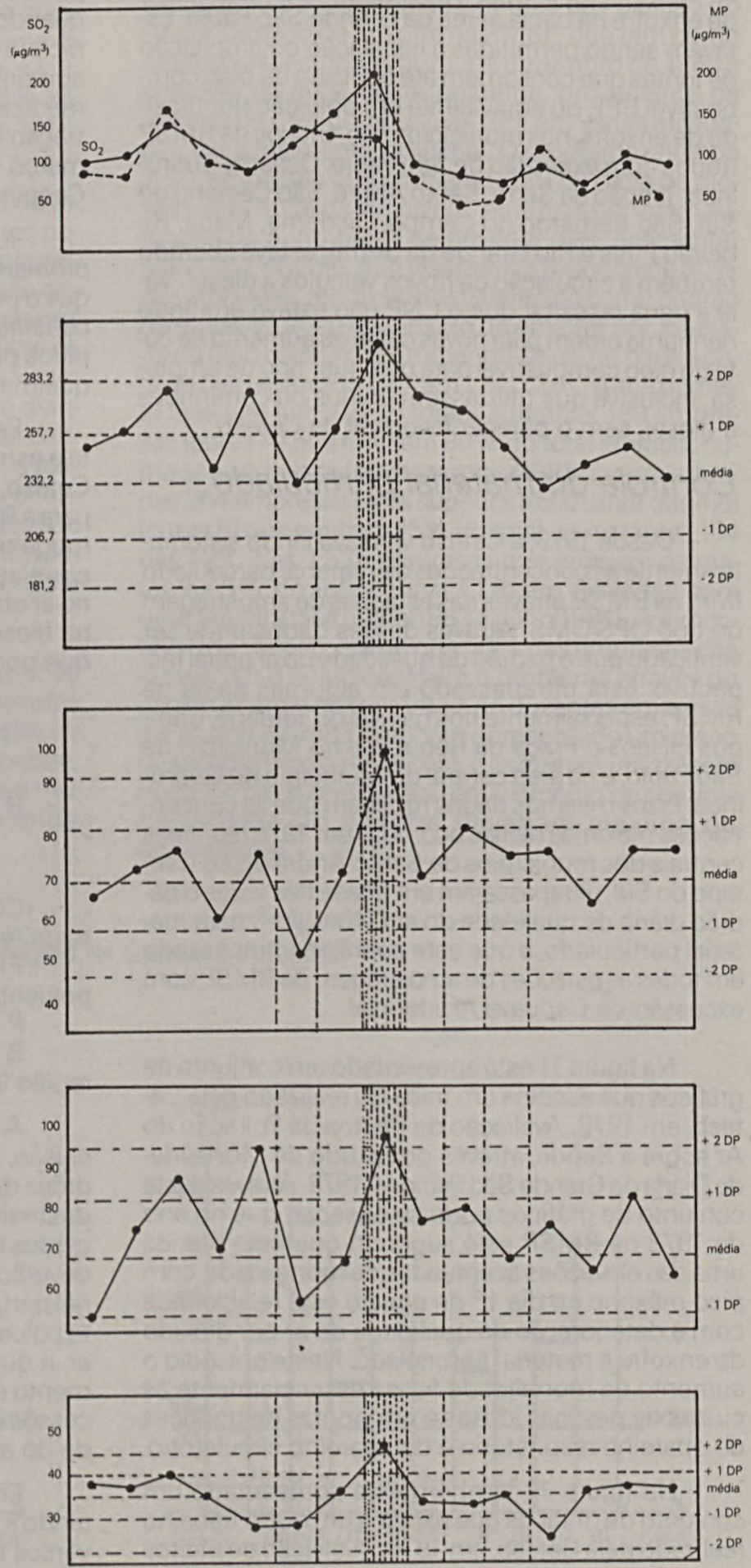

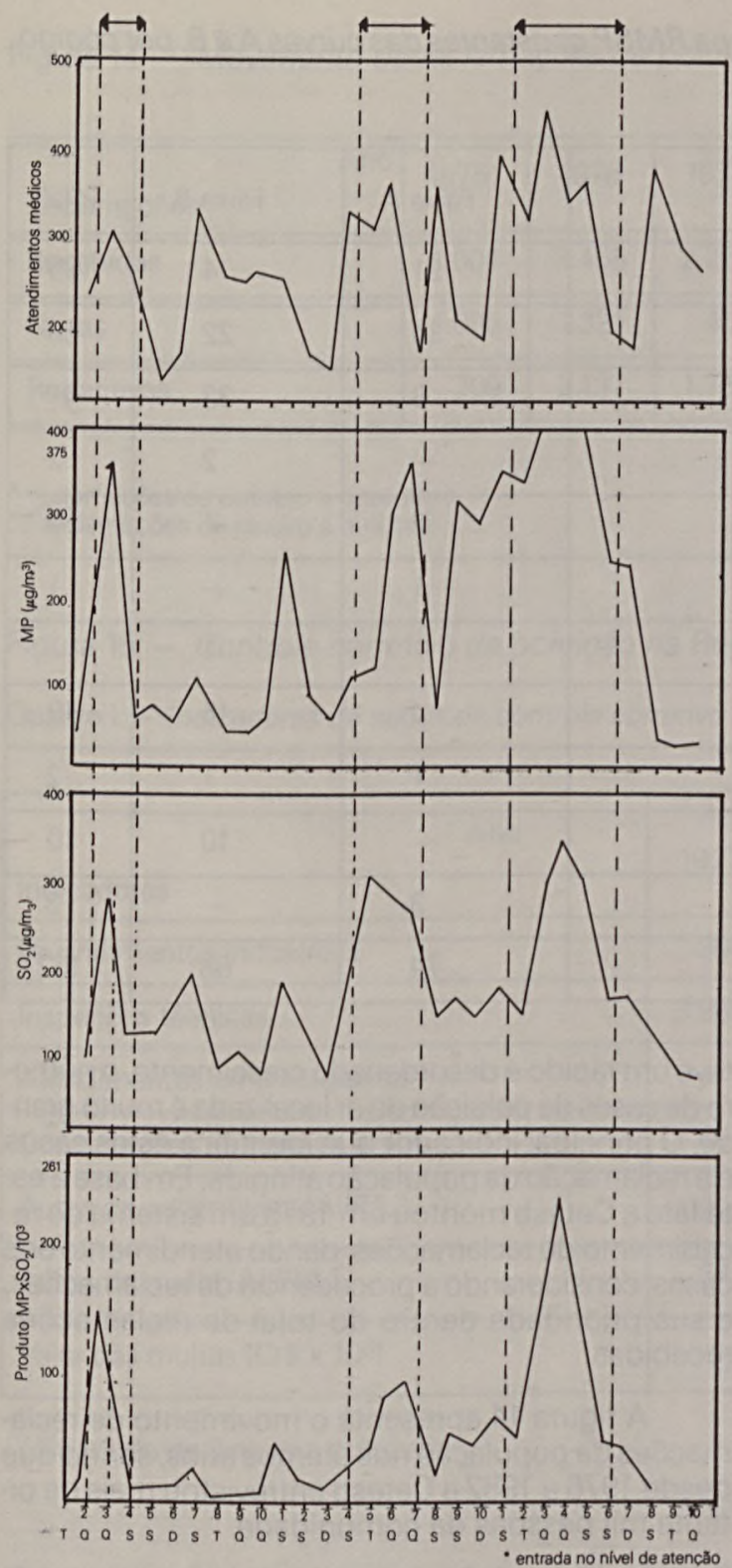

Figura 12 - Distribuição do número de atendimentos médicos, de material particulado (MP), dióxido de enxofre $\left(\mathrm{SO}_{2}\right)$ e do produto $\left(\mathrm{MP} \times \mathrm{SO}_{2}\right)$, dia a dia (junho de 1973)

a Cetesb determinou os padrões de emissão para material particulado, para a RMSP, já estabelecidos na legislação estadual.

A Cetesb iniciou em março de 1980, de uma forma sistemática, o Programa de Controle de Material Particulado na RMSP, visando atingir a redu- ção anteriormente apontada. O último inventário, reformulado pela Cetesb, das fontes industriais de material particulado foi apresentado em marco de 1981. Através deste, 1.050 indústrias emitiam 396t/dia de material particulado na atmosfera. Destas, 74 emitiam $90 \%$ do total (curva A), 88 emitiam $7,5 \%$ (curva B) e as restantes, 888 , emitiam $2,5 \%$ do total (curva C). Na figura 13 estão apresentadas as indústrias das curvas A e B por tipo de atividade, predominando as de extração e tratamento de minerais, as de produtos de minerais não-metálicos e as metalúrgicas.

Em outubro de 1982, as 162 indústrias estavam emitindo 233t/dia de material particulado. Comparando as emissões em novembro de 1978 constante na figura 1,399t/dia, podemos afirmar que houve uma redução de 166t/dia durante este período, o que representou cerca de $40 \%$. Até dezembro de 1983 , espera-se uma redução de aproximadamente mais $148 \mathrm{t} / \mathrm{dia}$, atingindo um total de $314 \mathrm{t} / \mathrm{dia}$ no período novembro 1978/dezembro 1983 e o atingimento da meta prevista.

Contudo, comparando-se a emissão potencial das 162 fontes, que é de 1.525t/dia, a redução até novembro de 1978 foi de $1.292 \mathrm{t} / \mathrm{dia}$, ou $85 \%$. Este é o resultado do trabalho que vinha sendo desenvolvido pelo governo do Estado de São Paulo desde 1972, através de seus organismos, inicialmente a Superintendência de Saneamento Ambiental - Susam, e a seguir, a partir de abril/1975, a Cetesb.

O crescimento de $5 \%$ ao ano previsto nas emissões de material particulado na RMSP está sendo controlado, utilizando-se o sistema de licenciamento como ferramenta básica. Estava sendo exigido das novas instalações e ampliações das indústrias existentes a utilização de sistemas de controle de poluição do ar, baseados na melhor tecnologia prática disponível. Determinados processos altamente poluidores da atmosfera em termos de material particulado foram também proibidos de se instalar ou, se já existentes, ampliarem-se na RMSP. A Lei Estadual n. 1.817 , de 27 de outubro de 1978 , proibe, entre outros, os seguintes tipos de indústrias: fundições de metais ferrosos ou não-ferrosos; refinarias de petróleo; beneficiamento e preparação de minerais nãometálicos; etc. A indústria de cimento sofre também sérias restrições para instalar-se ou ampliar-se na RMSP.

Para assegurar o sucesso deste plano, o governo do Estado de São Paulo, com o apoio do Banco Mundial, colocou à disposição das indústrias poluidoras um programa de assistência financeira denominado Procop. Este programa, que previa a aplicação de US\$ 187 milhões em controle de poluição ambiental, dos quais US\$ 104 milhões em controle de 
Figura 13 - Indústrias que emitem material particulado na RMSP constantes das curvas A e B, por código de atividades

\begin{tabular}{|l|c|c|c|}
\hline Código de atividade & Faixa A & Faixa B & Total \\
\hline 00 - Extração e tratamento de minerais & 21 & 4 & 25 \\
\hline 10 - Indústria de produtos de minerais não-metálicos & 34 & 22 & 56 \\
\hline 11 - Metalúrgica & 8 & 33 & 41 \\
\hline 13 - Indústria de mineral elétrico e de comunicação & - & 2 & 2 \\
\hline 14 - Indústria de material de transporte & 2 & - & 2 \\
\hline 17 - Indústria de papel e papelão & 1 & - & 1 \\
\hline 18 - Indústria de borracha & - & 1 & 1 \\
\hline 20 - Indústria química & 4 & 15 & 19 \\
\hline 22 - Indústria de perfumaria, sabões e velas & 1 & 1 & 2 \\
\hline 26 - Indústria de produtos alimentares & - & 10 & 10 \\
\hline 31 - Indústria de utilidade pública & 3 & - & 3 \\
\hline \multicolumn{1}{|c|}{ Total } & 74 & 88 & 162 \\
\hline
\end{tabular}

material particulado, estava constituído por uma linha de financiamento subsidiada, e com prazos de carência (três a cinco anos) e amortização (dez a quinze anos) bastante aceitáveis no mercado financeiro.

\section{Poluição localizada}

O modelo proporcional, utilizado na determinação dos padrões de emissão, não leva em consideração a distribuição espacial das fontes de poluição do ar da região considerada. Este modelo visa a atmosfera da bacia aérea como um todo, no sentido de se obter nela níveis de poluentes compativeis com os padrões de qualidade do ar. Desta forma, é necessário considerar-se na estratégia de controle, um mecanismo que leve em consideração a localização da fonte de poluição, com relação aos receptores mais atingidos, ou seja, que leve em consideração casos de poluição do ar localizados.

Também em relação a poluentes para os quais não foram estabelecidos padrões de emissão ou mesmo de qualidade de ar, ocorrem casos de poluição localizada, especialmente odores, para os quais a estratégia de controle deve prever uma ação visando proteger a saúde e o bem-estar dos receptores atingidos.

Numa região como a da Grande São Paulo, que teve um rápido e desordenado crescimento, o número de casos de poluição do ar localizada é muito grande. O principal indicador que identifica estes casos é a reclamação da população atingida. Em base a este fato a Cetesb montou em 1975 um sistema de recebimento de reclamações, dando atendimento aos casos, considerando a procedência de reclamações, e sua prioridade dentro do total de reclamações recebidas.

A figura 14 apresenta o movimento de reclamações da população nos últimos anos, sendo que desde 1976 a 1982 a Cetesb entrevistou mais de oitenta mil pessoas da comunidade.

Nos casos de poluição localizada, as exigências de controle da Cetesb estão baseadas na meIhor tecnologia prática disponível, mesmo para aquelas fontes para as quais, foram estabelecidas padrões de emissão. Esta ação está prevista na legislação existente, que ainda prevê que a Cetesb poderá exigir a relocação da fonte no caso em que previamente se sabe que a adoção de sistemas de controle não trará solução do problema de poluição localizada.

Na figura 15 estão apresentados alguns indicadores da ação corretiva da Cetesb sobre as fontes estacionárias e fontes móveis (óleo diesel) na RMSP. 
Figura 14 - Movimento de reclamações de poluição do ar da Região da Grande São Paulo (1975 - 1982)

\begin{tabular}{|c|c|c|c|c|c|c|c|c|c|}
\hline Reclamações Ano & $1975^{*}$ & 1976 & 1977 & 1978 & 1979 & 1980 & 1981 & $1982^{*}$ & Total \\
\hline Recebidas & 1.804 & 3.458 & 2.256 & 3.678 & 4.292 & 5.294 & 5.269 & 4.686 & 30.737 \\
\hline Novas & 1.095 & 1.321 & 467 & 362 & 522 & 464 & 439 & 358 & 5.028 \\
\hline Repetitivas & 709 & 2.137 & 1.789 & 3.316 & 3.770 & 4.830 & 4.830 & 4.328 & 25.709 \\
\hline
\end{tabular}

: reclamações de outubro a dezembro

* reclamações de janeiro a outubro

Figura 15 - Controle corretivo da poluição na Região Metropolitana de São Paulo

Quadro I - Indicadores de ações de controle corretivo de fontes estacionárias.

\begin{tabular}{|c|c|c|c|c|c|c|c|}
\hline $\begin{array}{ll} & \text { Ano } \\
\text { Indicadores } & \end{array}$ & 1977 & 1978 & 1979 & 1980 & 1981 & $1982^{\circ}$ & Total \\
\hline Levantamentos industriais & 366 & 366 & 489 & 732 & 511 & 248 & 2.712 \\
\hline Inspeções técnicas & 3.965 & 5.010 & 5.075 & 2.679 & 3.790 & 3.467 & 23.986 \\
\hline Atendimentos de emergência & - & 79 & 130 & 189 & 67 & 39 & 504 \\
\hline Constatações de fumaça preta & 887 & 447 & 412 & 364 & 433 & 298 & 2.841 \\
\hline Autos de advertência (AllPA $A_{S}$ ) & 1.893 & 1.538 & 1.154 & 973 & 979 & 788 & 7.325 \\
\hline Autos de multa (AllPMs) & 542 & 496 & 338 & 456 & 400 & 422 & 2.654 \\
\hline Valor das multas $\left(\mathrm{Cr} \$ \times 10^{6}\right)$ & 2,3 & 4,2 & 3,0 & 17,5 & 70,1 & 70,8 & 167,9 \\
\hline
\end{tabular}

* período de janeiro a outubro

Quadro II - Indicadores da fiscalização de veículos a diesel.

\begin{tabular}{|c|c|c|c|c|c|c|c|c|}
\hline Indicadores & Ano & 1977 & 1978 & 1979 & 1980 & 1981 & $1982^{\circ}$ & Total \\
\hline Constatações com autuações & & 472 & 1.195 & 1.517 & 1.277 & 1.200 & 865 & 6.526 \\
\hline Autos de advertência (AllPA ${ }_{s}$ ) & & 218 & 855 & 1.167 & 1.035 & 1.162 & 861 & 5.298 \\
\hline Autos de multa (AllPM ${ }_{s}$ ) & & 1.601 & 247 & 258 & 250 & 22 & 3 & 2.381 \\
\hline Valor das multas $\left(\mathrm{Cr} \$ \times 10^{6}\right)$ & & 2,1 & 0,4 & 1,2 & 1,7 & 0,5 & 0,1 & \\
\hline
\end{tabular}

- período de janeiro a outubro 


\section{Conclusões}

É sério o problema de poluição do ar na Região Metropolitana de São Paulo - RMSP, onde as concentrações, na atmosfera dos poluentes dióxido de enxofre, material particulado, monóxido de carbono e oxidantes fotoquímicos, estão acima dos respectivos padrões de qualidade do ar, tornando-a uma região saturada em termos de poluição do ar, conforme estabelecido em legislação estadual.

As ações de controle de poluição do ar, que vem sendo desenvolvidas pelo governo do Estado de São Paulo, já há quase dez anos, lograram diminuir o risco de episódios agudos de poluição do ar durante o período de inverno, bem como evitar o agravamento do problema de poluição do ar por material particulado, apesar de que em algumas áreas, não-industriais da região, este apresente uma tendência crescente.

As ações de controle de poluição do ar, preventivas e corretivas, que estavam sendo desenvolvidas pelo governo do Estado de São Paulo para o controle de material particulado por fontes estacionárias, bem como, mais recentemente, para controle de dióxido de enxofre por fontes que queimam óleo combustível devem ter continuidade, tendo em vista proteção à saúde da população.

Tendo em vista o agravamento do problema de poluição do ar por dióxido de enxofre na RMSP, independente do programa de controle deste poluente referido na conclusão anterior deverá ser mantida a utilização de óleo de baixo teor de enxofre durante o período de inverno para os grandes consumidores desta região, bem como desencadear imediatamente um programa que restrinja a circulação de veículos a diesel no chamado "Grande Centro" de São Paulo, utilizando, por exemplo, no caso de transportes coletivos, os ônibus elétricos. Esta medida proporcionaria, também, como benefício, a redução de material particulado no ar de áreas urbanas nãoindustrializadas.

Devem ser rapidamente ultimados os estudos visando obtenção das reduções necessárias nas emissões de monóxido de carbono, hidrocarbonetos e óxidos de nitrogênio nos veículos novos movidos à gasolina ou à mistura gasolinalálcool etílico $(\approx 20 \%)$, a fim de que o governo do Estado de São Paulo possa gestionar junto ao governo federal, especialmente junto à Secretaria Especial do Meio Ambiente - SEMA e ao Conselho Nacional do Trânsito - Contran, o estabelecimento de padrões de emissão que, segundo a legislação federal, é de competência exclusiva do Conselho Nacional do Meio Ambiente - Conama.
Devem ser acelerados os estudos visando a obtenção de dados de emissão de veículos novos movidos a álcool etílico, especialmente no que diz respeito à emissão de aldeídos, bem como os estudos de aldeídos na atmosfera da RMSP, visando levantar os verdadeiros riscos causados pela maior emissão ( $\approx 450 \%$ a mais) desse poluente na atmosfera.

Deve ser mantida a estratégia de não estabelecer exigências de controle para veículos em circulação, tendo em vista o alto custo envolvido e o duvidoso benefício advindo.

Devem ser incentivadas as medidas de controle de poluição do ar que visem a adequada localizacão e distribuição das fontes estacionárias no espaço da RMSP, bem como aquelas que se compatibilizem com a Política Energética Nacional.

Devem ser desincentivadas aquelas alternativas de controle que vinculam tecnologia alienígena ao equacionamento e solução dos problemas, e que não tenham o devido respaldo popular.

\section{Bibliografia}

ASSUNCุÃO, JV. de. Comparação entre emissões de veículos a álcool e à gasolina. In: XI CONGRESSO BRASILEIRO DE ENGENHARIA SANITÁRIA E AMBIENTAL. Fortaleza, 1981.

CANCEGLIERO, C.L. et alii. Sistema de coleta, análise e interpretação de dados de qualidade de ar na Região da Grande São Paulo. In: X CONGRESSO BRASILEIRO DE ENGENHARIA SANITARIA E AMBIENTAL. Manaus, 1979.

CETESB. Companhia de Tecnologia de Saneamento Ambiental. Ava liação da qualidade do ar; rede de estações. Manaus, resumo de dados - 1973/1981. São Paulo, Diretoria de Engenharia do Ar e de Ação Metropolitana, 1982.

CETESB. Companhia de Tecnologia de Saneamento Ambiental, De senvolvimento de padrões de emissão para veículos leves do ciclo otto. P.J. 3.1. da Diretoria de Engenharia do Ar e Ação Metropolitana. São Paulo, 1983. Fase 1.

CHRISTO, A de et alii. A importância do estudo comunitário para o controle da poluição ambiental. In: X CONGRESSO BRA SILEIRO DE ENGENHARIA SANITARIA E AMBIENTAL. Ma naus, 1979.

DERISIO, J.C. O controle da poluição do ar e a ação corretiva na Região da Grande São Paulo. In: X CONGRESSO BRASILEIRO DE ENGENHARIA SANITÁRIA E AMBIENTAL. Manaus, 1979 .

ESTEVES, S.S. et alii. Niveis de poluição sonora na Região da Grande São Paulo. In: X CONGRESSO BRASILEIRO DE ENGENHARIA SANITARIA E AMBIENTAL. Manaus, 1979.

FERNICOLA, N.A.G.G. de \& LIMA, E.R. Niveis de carboxihemoglobina em habitantes da cidade de São Paulo. Cetesb. Diretoria de Tecnologia do Ar e de Ação Metropolitana, 1977

GALVÃO FILHO, J.B. et alii. A utilização do carvão mineral no Estado de São Paulo e seu impacto no ambiente. In: ANAIS DO 5. CONGRESSO INTERNACIONAL DEL AIRE PURO. BuenoS Aires, 1980. 
GODINHO, R. et alii. Ocorrência de aldeídos na atmosfera da Grande São Paulo. In: XI CONGRESSO BRASILEIRO DE ENGENHARIA SANITÁRIA E AMBIENTAL, Fortaleza, 1981.

HASEGANA, P.T. et alii. Guias industriais, ferramentas para o controle da poluição do meio ambiente no Estado de São Paulo. In: $X$ CONGRESSO BRASILEIRO DE ENGENHARIA SANITÁ RIA E AMBIENTAL. Manaus, 1979.

MENDES, R. \& WAKAMATSU, C.T. Avaliação dos efeitos agudos da poluição do ar sobre a saúde através do estudo da morbidade diária em São Caetano do Sul, São Paulo, Cetesb. Diretoria de Engenharia do Ar e Ação Metropolitana, 1976.

. Avaliação dos efeitos da poluição do ar sobre a saúde através do estudo de morbidade diária na Grande São Paulo 1976. São Paulo, Cetesb. Diretoria de Engenharia do Ar e Acão Metropolitana, 1977.

MESQUITA, A.L.S. et alii. Engenharia de ventilação industrial. São Pau lo, Cetesb, Edgard Blüchner Ltda, 1977.

\& NEFUSSI, N. Política de controle de poluição do ar no
Estado de São Paulo. Rio de Janeiro. Rev. Brasileira de Engenharia Sanitária, (1), 1981.

NEFUSSI, N. Poluição do ar nas áreas metropolitanas, estudo atual do problema em São Paula. In: III SEMINÁRIO LATINO AMERICANO DE AVALIAÇÃO EPIDEMOLOGICA DE RISCOS AMBIENTAIS. Campinas, 1982.

OLIVEIRA, G. et alii. Autofinanciamento dos programas de controle da poluição ambiental no Estado de São Paulo. In: X CONGRESSO BRASILEIRO DE ENGENHARIA SANITÁRIA EAMBIENTAL. Manaus, 1979:

OLIVEIRA, S. de \& ALMEIDA, M.A.L. de Sistema de previsão me teorológica aplicada à poluição do ar na Região da Grande São Paula In: X CONGRESSO BRASILEIRO DE ENGENHA RIA SANITÁRIA E AMBIENTAL. Manaus, 1979.

OLIVEIRA, W. et alii, Rede automática de amostragem de poluentes atmosféricos instalada na Região da Grande São Paulo. In: X CONGRESSO BRASILEIRO DE ENGENHARIA SANITÁRIA E AMBIENTAL. Manaus, 1979 
